\title{
Studies on Lipolysis in Human Adipose Cells *
}

\author{
David J. Galton † and George A. Bray \\ (From the New England Medical Center Hospitals and the Department of Medicine, Tufts \\ University School of Medicine, Boston, Mass.)
}

\begin{abstract}
Summary. Epinephrine stimulated lipolysis and the uptake of oxygen by subcutaneous adipose cells of man. When glucose- $-{ }^{14} \mathrm{C}$ was present in the medium, its utilization was not increased by epinephrine, although lipolysis was accelerated. Insulin did not reduce the production of fatty acids that had been stimulated by epinephrine.

The combination of human growth hormone and cortisol stimulated the production of fatty acids by isolated human adipose cells to a lesser extent than epinephrine. When human growth hormone or cortisol was used singly, or when bovine growth hormone was added in combination with cortisol, no effect on fatty acid production was observed. Furthermore, an acetone-dried preparation of human pituitary glands, which was shown to stimulate lipolysis in rat adipose cells, had no effect on fatty acid formation in human adipose cells. This suggested that the human pituitary gland contained no more potent lipolytic agents than growth hormone and was supported by the lack of response of human adipose cells to purified corticotropin.
\end{abstract}

\section{Introduction}

Starvation in man and other mammals produces an increase in the concentration of free fatty acids in the plasma (1). It has been claimed that the sympathetic nervous system (2) or growth hormone (3), possibly in combination with a glucocorticoid (4) or a state of insulin deficiency (5), is responsible for this phenomenon. Since plasma fatty acids mainly originate from adipose tissue, the first two hypotheses imply that epinephrine or growth hormone (with a glucocorticoid) is capable of stimulating lipolysis in this tissue.

A possible way to assess the relative importance of these hormones in raising the plasma levels of fatty acids in man is to examine their

* Submitted for publication May 5, 1966 ; accepted December 30, 1966.

Supported by U. S. Public Health Service grants AM-612 and AM 9897.

Part of this work has been reported in abstract form (J. clin. Invest. 1966, 45, 1010).

† Fellowship from National Institute of Arthritis and Metabolic Diseases 1965 to 1966, grant AM-29,650.

Address requests for reprints to Dr. David J. Galton, New England Medical Center Hospitals, Boston, Mass. 02111 . effects on lipolysis in human adipose tissue in vitro. This is not to suggest that the findings from such simplified experiments can be directly applied to the complex physiological state of fasting, but experiments such as those reported here provide some guide for the analysis of the complex conditions existing in the whole animal.

\section{Methods}

Source of tissue. Human subcutaneous adipose tissue was obtained during abdominal operations from a total of 41 patients (Tables I and II). Patients with diabetes and jaundice were excluded. Preoperative treatment involved a fast of 8 hours and premedication with sodium pentobarbital and general anesthesia induced by thiopental sodium and maintained with the agents listed in the Tables. Twice it was possible to obtain adipose tissue from the abdominal wall of patients undergoing spinal anesthesia, and the activity of their adipose cells is compared with that of the tissue of patients adjacent in the series who had undergone general anesthesia (Table III). It appears from this that general anesthesia does not markedly inhibit the metabolism of adipose tissue. The adipose tissue was removed most frequently at the time of the first incision, though on some occasions the tissue was obtained just before closure of the wound. After removal, the tissue was washed and placed on a gauze soaked in saline $(0.9 \%)$. Dermis and epidermis were dis- 
TABLE I

Clinical details of the patients employed in this study

\begin{tabular}{|c|c|c|c|c|c|}
\hline Patient & Age & Sex & Wt & Anesthetic agent & Operation \\
\hline & years & & pounds & & \\
\hline R.B. & 52 & $\mathrm{~F}$ & 150 & Cyclopropane & Vaginal repair \\
\hline M.M. & 31 & $\mathrm{~F}$ & 122 & Halothane, nitrous oxide & Herniorrhaphy \\
\hline N.W. & 26 & $\mathrm{M}$ & 238 & Halothane, nitrous oxide & Laminectomy \\
\hline D.C. & 60 & $\mathbf{M}$ & 188 & Cyclopropane & Repair gastrocolic fistula \\
\hline J.C. & 70 & $\mathrm{M}$ & 166 & Halothane & Laminectomy \\
\hline B.W. & 66 & $\mathrm{~F}$ & 72 & Halothane & Adrenalectomy \\
\hline J.A. & 34 & $\mathrm{~F}$ & 140 & Halothane & Laminectomy \\
\hline N.L. & 44 & $\mathrm{~F}$ & & Cyclopropane & Colostomy \\
\hline A.C. & 41 & $\mathrm{M}$ & & Cyclopropane & Gastrojejunostomy \\
\hline E.B. & 46 & $\mathbf{M}$ & 179 & Halothane, nitrous oxide & Sympathectomy, lumbar \\
\hline O.J. & 44 & $\mathrm{~F}$ & & Cyclopropane & Gastrectomy \\
\hline C.T. & 56 & $\mathbf{M}$ & 188 & Halothane & Repair aneurysm (abdominal) \\
\hline W.M. & 32 & $\mathrm{~F}$ & 167 & Cyclopropane & Cholecystectomy \\
\hline C.M. & 54 & $\mathrm{~F}$ & & Cyclopropane & Hysterectomy \\
\hline Y.J. & 42 & $\mathrm{~F}$ & 145 & Cyclopropane & Hysterectomy \\
\hline W.K. & 45 & $\mathrm{M}$ & 150 & Penthrane & Spinal fusion \\
\hline C.R. & 48 & $\mathbf{M}$ & 186 & Halothane, nitrous oxide & Cholecystectomy \\
\hline S.T. & 17 & $\mathrm{~F}$ & 173 & Penthrane, nitrous oxide & Appendectomy \\
\hline E.M. & 31 & $\mathrm{~F}$ & 182 & Cyclopropane & Hysterectomy \\
\hline M.M. & 64 & $\mathrm{~F}$ & 115 & Nupercaine & L. nephrectomy \\
\hline R.D. & 64 & M & 175 & Pontocaine & Suprapubic prostatectomy \\
\hline H.B. & 65 & M & 144 & Halothane, nitrous oxide & Bilateral sympathectomy \\
\hline R.G. & 76 & $\mathrm{M}$ & 154 & Halothane, nitrous oxide & Gastrectomy \\
\hline R.L. & 16 & M & 113 & Cyclopropane & Abdominal perineal resection \\
\hline H.L. & 57 & $\mathrm{~F}$ & 185 & Cyclopropane & Polypectomy \\
\hline P.C. & 51 & $\mathrm{~F}$ & 165 & Cyclopropane & Repair of hernia \\
\hline O.C. & 24 & $\mathrm{~F}$ & 121 & Cyclopropane & Repair of hernia \\
\hline
\end{tabular}

sected away with a pair of fine scissors. The adipose tissue was then cut with scissors into small pieces (approximately 5 to $10 \mathrm{~mm}$ in diameter), and any thick strands of connective tissue were removed. The tissue pieces (up to $2 \mathrm{~g}$ per vessel) were placed in $3 \mathrm{ml}$ of an albumin-bicarbonate buffer without glucose in conical flasks that had been siliconized, and adipose cells were isolated by the method of Rodbell (6). Approximately 30 to $50 \mathrm{mg}$ of collagenase was in the flasks, and the tissue was incubated in a water bath at $37^{\circ}$ under a gas phase of $\mathrm{CO}_{2}+\mathrm{O}_{2}(5: 95)$. At the end of incubation, which varied from 30 to 60 minutes depending on the activity of the collagenase preparation, the contents of the conical flasks were transferred to polyethylene tubes. The remaining tissue was gently ground with a piece of polyethylene tubing, and the tubes were then centrifuged at $300 \times g$ for approximately 1 minute. The liquid-fat layer (derived from broken cells), the sediment, and the infranatant were discarded; the supernatant, which contained free adipose cells and small clumps of adipose cells, was washed two to three times with fresh albuminbicarbonate buffer. After the final washing the infranatant was discarded, and the lightly packed cells were transferred to the experimental vials or Warburg flasks.

Materials. All reagents were analytical grade. The bicarbonate buffer was composed of $\mathrm{NaCl}(127 \mathrm{mM})$, $\mathrm{KCl}(2.7 \mathrm{mM}), \mathrm{CaCl}_{2}(1.4 \mathrm{mM}), \mathrm{MgCl}_{2}(0.5 \mathrm{mM})$, $\mathrm{NaHCO}_{3}(12 \mathrm{mM})$, and $\mathrm{NaH}_{2} \mathrm{PO}_{4}(4 \mathrm{mM})$. The albu- min-bicarbonate buffer was freshly prepared for each experiment and contained Fraction $\mathrm{V}$ bovine albumin, ${ }^{1} 1 \mathrm{~g}$ per $100 \mathrm{ml}$ (wt/vol) for the collagenase digestion and 4 $\mathrm{g}$ per $100 \mathrm{ml}$ (wt/vol) for the experiments on lipolysis. The buffer was gassed with a $\mathrm{CO}_{2}+\mathrm{O}_{2}$ mixture $(5: 95)$ and its $\mathrm{pH}$ adjusted to 7.3. The Krebs-Ringer phosphate buffer was modified to contain $\mathrm{NaCl}(150 \mathrm{mM}), \mathrm{KCl}$ (6.2 $\mathrm{mM}), \mathrm{CaCl}_{2}(0.8 \mathrm{mM}), \mathrm{KH}_{2} \mathrm{PO}_{4}(0.1 \mathrm{mM}), \mathrm{MgSO}_{4}$ $(0.1 \mathrm{mM})$, and phosphate buffer $(12 \mathrm{mM})$. It was prepared daily before use and contained $4 \mathrm{~g}$ per $100 \mathrm{ml}$ (wt/vol) of Fraction V bovine albumin (lot 21908) at $7.2 \mathrm{pH}$. The agents used were the following: soluble insulin, ${ }^{2}$ diluted in albumin-bicarbonate buffer to contain $0.1 \mathrm{U}$ per $\mathrm{ml}$; epinephrine hydrochloride, ${ }^{3}$ diluted in 0.15 $\mathrm{M}$ sodium chloride; human growth hormone, ${ }^{4}$ dissolved in $0.01 \mathrm{~N} \mathrm{HCl}$ and stored at $4^{\circ}$; Oxycel-purified corticotropin, ${ }^{5}$ dissolved in $0.01 \mathrm{~N} \mathrm{HCl}$; hydrocortisone, ${ }^{6}$ dissolved in absolute ethyl alcohol and then diluted with saline to give a concentration of $0.2 \mathrm{mg}$ per $\mathrm{ml}$; crude human pituitary powder, ${ }^{4}$ suspended in albumin buffer be-

1 Armour Pharmaceutical Co., Kankakee, Ill.

2 Iletin-U-40, Eli Lilly and Co., Indianapolis, Ind.

3 Adrenaline, Parke, Davis and Co., Detroit, Mich.

${ }^{4}$ Kindly supplied by Dr. M. S. Raben.

5 Corticotropin, Wilson Labs., Chicago, Ill.

${ }^{6}$ Hydrocortisone alcohol, Sigma Chemical Co., St. Louis, Mo. 
TABLE II

Effects of human growth hormone and cortisol on production of fatty acids by isolated human fat cells*

\begin{tabular}{|c|c|c|c|c|c|c|c|c|}
\hline \multirow[b]{4}{*}{ Name } & \multirow[b]{4}{*}{ Age } & \multirow[b]{4}{*}{ Sex } & \multirow[b]{4}{*}{ wt } & \multirow[b]{4}{*}{ Anesthetic agent } & \multirow[b]{4}{*}{ Operation } & \multicolumn{3}{|c|}{ Fatty acid production } \\
\hline & & & & & & \multirow[b]{3}{*}{ Control } & \multicolumn{2}{|c|}{ Human growth hormone } \\
\hline & & & & & & & $5 \mu \mathrm{g} / \mathrm{ml}$ & $2.5 \mu \mathrm{g} / \mathrm{ml}$ \\
\hline & & & & & & & \multicolumn{2}{|c|}{ Cortisol, ${ }^{+} \mu \mathrm{g} / \mathrm{ml}$} \\
\hline & years & & pounds & & & \multicolumn{3}{|c|}{ $\mu$ moles/mmole TG/4 hr $\dagger$} \\
\hline E.L. & 53 & F & 152 & $\begin{array}{l}\text { Halothane, } \\
\text { nitrous oxide }\end{array}$ & Oophorectomy & 0.00 & 0.79 & 0.45 \\
\hline G.V. & 54 & $\mathrm{~F}$ & 136 & $\begin{array}{l}\text { Cyclopropane, } \\
\text { oxygen }\end{array}$ & Vaginal repair & -0.16 & 1.9 & 0.38 \\
\hline C.W. & 70 & M & 160 & Cyclopropane & Cholecystectomy & 0.32 & 0.78 & 0.59 \\
\hline M.A. & 51 & M & 159 & Cyclopropane & Pancreatic biopsy & 0.69 & 1.05 & 0.67 \\
\hline S.E. & 48 & $\mathrm{~F}$ & 89 & Cyclopropane & Hysterectomy & -0.43 & -0.20 & -0.30 \\
\hline C.M. & 48 & $\mathrm{~F}$ & 178 & Cyclopropane & Appendectomy & 0.12 & 0.29 & 0.33 \\
\hline E.M. & 21 & $\mathrm{~F}$ & 134 & $\begin{array}{l}\text { Halothane, } \\
\text { nitrous oxide }\end{array}$ & Splenectomy & -0.56 & -0.31 & \\
\hline L.F. & 54 & $\mathrm{~F}$ & 148 & $\begin{array}{l}\text { Halothane, } \\
\text { nitrous oxide }\end{array}$ & $\begin{array}{l}\text { Bilateral lumbar } \\
\text { sympathectomy }\end{array}$ & 0.05 & 0.10 & \\
\hline L.L. & 32 & $\mathrm{~F}$ & & $\begin{array}{l}\text { Halothane, } \\
\text { nitrous oxide }\end{array}$ & $\begin{array}{l}\text { Renal arterial } \\
\text { explant }\end{array}$ & 0.16 & -0.29 & \\
\hline W.C. & 34 & $\mathbf{M}$ & 176 & Pontocaine & $\begin{array}{l}\text { Left inguinal } \\
\text { herniorrhaphy }\end{array}$ & 0.40 & 0.44 & \\
\hline \multirow[t]{3}{*}{ E.B. } & 32 & F & 224 & Cyclopropane & Appendectomy & -0.53 & -0.24 & \\
\hline & & & & & Mean: & 0.005 & 0.39 & 0.35 \\
\hline & & & & & $p$ versus control: & & 0.005 & \\
\hline
\end{tabular}

* Isolated fat cells (approximately $200 \mu$ moles of triglyceride) were incubated for 4 hours in 2 ml of albumin-bicarbonate buffer containing glucose $(5.6 \mathrm{mM})$. The results are values of individual experiments. The significance of the difference $\mathrm{p}$ was calculated by a nonparametric sign test (11).

$\dagger \mathrm{TG}=$ triglyceride.

fore use; porcine pituitary glands (lyophilized), ${ }^{7}$ treated in a similar manner; and glucose- ${ }^{14} \mathrm{C}, 8$ added to incubation flasks to make a final specific activity of $0.02 \mu \mathrm{c}$ per $\mu$ mole.

Experimental design. Adipose cells were distributed among 3 to 20 flasks, depending on the amount of tissue available. Each flask contained 1 or $2 \mathrm{ml}$ of albumin buffer (as stated in the Tables) with the appropriate substrates and hormones added. Zero time samples were taken after 5 minutes' equilibration, but when small amounts of tissue were available a medium blank was used. We incubated the flasks under air when using a phosphate buffer or under a gas mixture of $\mathrm{CO}_{2}+\mathrm{O}_{2}$ (5:95) when bicarbonate buffer was used. Controls without special additions were carried out. At the end of incubation, the contents of the flasks were centrifuged at $300 \times g$, and a $200-\mu 1$ sample was removed from the infranatant for assay of glycerol. The reaction was then stopped by addition of $5 \mathrm{ml}$ of an extraction mixture for fatty acids.

Assay procedures. Oxygen consumption was mea-

7 Kindly given by Dr. E. B. Astwood.

8 New England Nuclear Corp., Boston, Mass. sured in conventional Warburg vessels as previously described (7). Fatty acids were extracted by a modification of the procedure of Dole and Meinertz (8), and titrations were carried out in $95 \%$ ( $\mathrm{vol} / \mathrm{vol}$ ) ethyl alcohol with Nile blue as indicator.

Glycerol was estimated by a modification of the method of Wieland (9)..$^{9}$ The reaction system contained the following : 200 to $500 \mu 1$ of the incubation medium, which was not deproteinized; glycerokinase, $1 \mu \mathrm{l}$ ( $5 \mathrm{mg}$ per $\mathrm{ml})$; glycerophosphate dehydrogenase, $5 \mu \mathrm{l}$ (10 mg per $\mathrm{ml}$ ); NAD, $0.3 \mathrm{mM}$; ATP, $0.6 \mathrm{mM}$; and hydrazine-glycine buffer $(0.8,0.16 \mathrm{M}, \mathrm{pH} 9)$ containing $2 \mathrm{mM} \mathrm{MgCl}_{2}$. We added enzymes last in $1 \%$ ( $\mathrm{vol} / \mathrm{vol}$ ) mercaptoethanol to make a final volume of $3 \mathrm{ml}$. Readings were performed in a spectrophotometer (Spectronic 20) at $340 \mathrm{~m} \mu 30 \mathrm{~min}$ utes after adding the enzymes. Standard curves were prepared for each experiment, and $0.1 \mu$ mole of glycerol gave an absorbency of approximately 0.18 .

Radioactivity. In some experiments, we added glucose${ }^{14} \mathrm{C}$ to the incubation medium to make a final specific activity of $0.02 \mu \mathrm{c}$ per $\mu$ mole glucose. At the end of the in-

\footnotetext{
${ }^{9}$ Reagents purchased from C. F. Boehringer and Sons, Mannheim, Germany.
} 
TABLE III

The effect of anesthesia on the metabolism of isolated human adipose cells*

\begin{tabular}{|c|c|c|c|c|c|}
\hline \multirow{2}{*}{$\begin{array}{c}\text { Experi- } \\
\text { ment } \\
\text { no. }\end{array}$} & \multirow[b]{2}{*}{ Patient, age, and sex } & \multirow[b]{2}{*}{ Anesthesia } & \multirow[b]{2}{*}{$\begin{array}{c}\text { Oxygen } \\
\text { uptake }\end{array}$} & \multicolumn{2}{|c|}{ Fatty acid production } \\
\hline & & & & Control & $\begin{array}{c}+ \text { Epi- } \\
\text { nephrine } \\
(5 \mu \mathrm{g} / \mathrm{ml})\end{array}$ \\
\hline & & & $\underset{T G / h r}{\mu l / m m o l e}$ & \multicolumn{2}{|c|}{$\begin{array}{c}\mu m o l e s / m m o l e \\
T G / h r\end{array}$} \\
\hline $\begin{array}{l}16 \\
17 \\
26 \\
27\end{array}$ & $\begin{array}{l}\text { F.P., 67, male } \\
\text { B.W., 66, female } \\
\text { D.C., 60, male } \\
\text { H.R., 66, male }\end{array}$ & $\begin{array}{l}\text { Spinal } \\
\text { General } \\
\text { General } \\
\text { Spinal }\end{array}$ & $\begin{array}{l}41 \\
33 \\
29 \\
40\end{array}$ & $\begin{array}{l}0.42 \\
1.6 \\
0.9 \\
0.30\end{array}$ & $\begin{array}{l}2.74 \\
4.8 \\
2.2 \\
2.1\end{array}$ \\
\hline
\end{tabular}

* Fat cells (approximately $465 \mu$ moles of triglycerides) were incubated in $2 \mathrm{ml}$ of an albumin-phosphate buffer without glucose for 2 hours. Epinephrine, when present, was added to make a final concentration of $5 \mu \mathrm{g}$ per $\mathrm{ml}$.

cubation period, the ${ }^{14} \mathrm{CO}_{2}$ from the medium was driven off with $0.5 \mathrm{ml}$ of $0.5 \mathrm{~N} \mathrm{H}_{2} \mathrm{SO}_{4}$ and trapped in a strip of filter paper soaked in $0.5 \mathrm{ml}$ of Hyamine [ $p$-(diisobutylcresoxyethoxyethyl) dimethylbenzyl ammonium hydroxide]. The paper was then transferred to $10 \mathrm{ml}$ of Bray's solution (10) and counted in a liquid scintillation counter.

Calculations. All statistical comparisons were based on means of paired experiments. The significance of the difference was tested where necessary by a nonparametric sign test, since this does not assume that the distribution of the data was normal (11). Results are expressed as micromoles of substrate per millimole triglyceride of adipose cells.

\section{Results}

The respiratory activity of isolated human adipose cells is shown in Figure 1. It required adipose cells equivalent to 200 to $300 \mu$ moles of triglycerides per flask before a reliable uptake of oxygen could be measured. Accordingly, these amounts of adipose cells were used in most of the following experiments.

Effects of epinephrine on lipolysis. Figure 2 is a dose-response curve which shows that epinephrine stimulates the production of fatty acids from isolated human fat cells. Adipose tissue cells as approximately $132 \mu$ moles of triglycerides were incubated in $2 \mathrm{ml}$ of an albumin-phosphate buffer with increasing concentrations of epinephrine for 1 hour without glucose. The values plotted as fatty acid production have zero time blanks and 1 -hour control values subtracted from them. Under the experimental conditions used, it was difficult to observe an effect of epinephrine below a concentration of $0.6 \mu \mathrm{g}$ per $\mathrm{ml}$, and the lowest point on Figure 1 is not significantly different from zero with the number of replications employed.
In a series of ten patients, epinephrine $(3 \mu \mathrm{g}$ per $\mathrm{ml}$ ) stimulated the production of fatty acids from isolated fat cells, and the oxygen consumption was also increased (Table IV). When insulin was added with epinephrine to the incubation medium, the increment in production of fatty acids and the stimulation of oxygen uptake were the same as with epinephrine alone (Table IV). In a further group of five patients (Table V) epinephrine $(3 \mu \mathrm{g}$ per $\mathrm{ml})$ produced a concurrent increase in oxygen consumption $(p=0.03)$ and in production of fatty acids and glycerol. When a smaller quantity of adipose cells was incubated

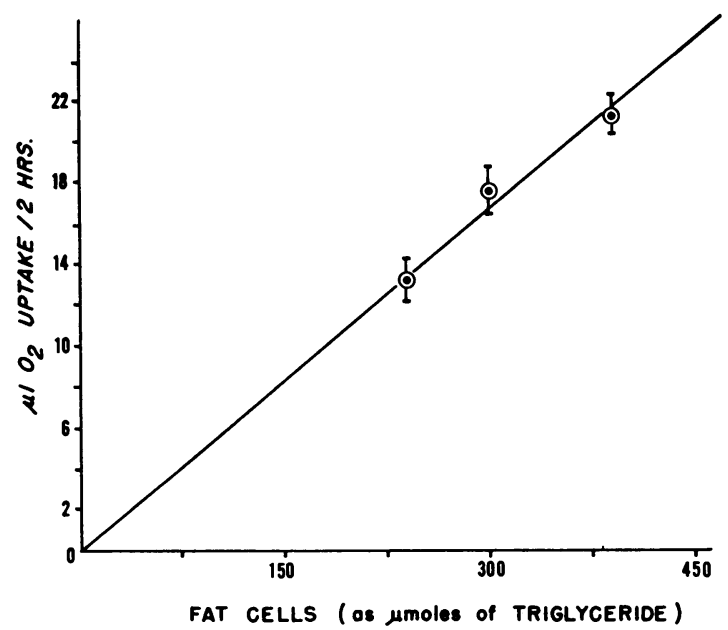

Fig. 1. Graph of OXYGEN CONSUMPtion of isolated HUMAN FAT CELLS (AS MICROMOLES OF TRIGLYCERIDE). Values are derived from individual plots of four experiments. This was done to allow for the variation in delivering 240,300 , and $390 \mu$ moles of triglycerides to each flask. Incubations were carried out under conditions described in Table I, and the standard error of the mean is represented between the bars. 
TABLE IV

Effects of epinephrine $(3 \mu \mathrm{g} / \mathrm{ml})$ and epinephrine with insulin $(1 \mathrm{mU} / \mathrm{ml})$ on oxygen uptake and fatty acid production by isolated human fat cells*

\begin{tabular}{|c|c|c|c|c|c|c|}
\hline \multirow[b]{2}{*}{ Treatment } & \multicolumn{3}{|c|}{ Oxygen uptake } & \multicolumn{3}{|c|}{ Fatty acid release } \\
\hline & $\begin{array}{c}\text { Control } \\
\text { without } \\
\text { hormone }\end{array}$ & $\begin{array}{l}\text { With } \\
\text { hormone }\end{array}$ & $\begin{array}{c}\mathbf{p} \\
\text { versus } \\
\text { control }\end{array}$ & $\begin{array}{c}\text { Control } \\
\text { without } \\
\text { hormone }\end{array}$ & $\begin{array}{l}\text { With } \\
\text { hormone }\end{array}$ & $\begin{array}{c}p \\
\text { versus } \\
\text { control }\end{array}$ \\
\hline & \multicolumn{3}{|c|}{$\mu l / m m o l e T G / h r$} & \multicolumn{3}{|c|}{ 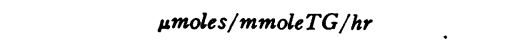 } \\
\hline Epinephrine & $25 \pm 4$ & $36 \pm 4$ & 0.05 & $0.43 \pm 0.09$ & $3.17 \pm 0.4$ & 0.001 \\
\hline $\begin{array}{c}\text { Epinephrine } \\
+ \text { insulin }\end{array}$ & $26 \pm 5$ & $35 \pm 6$ & 0.05 & $0.53 \pm 0.27$ & $2.40 \pm 0.45$ & 0.009 \\
\hline
\end{tabular}

* Approximately $450 \mu$ moles of triglyceride of adipose cells was incubated in $2 \mathrm{ml}$ of albumin-phosphate buffer for 1 hour with the indicated concentrations of hormones in the absence of glucose. Results are means of 10 experiments \pm standard errors of the mean. The significance of the difference was calculated by a nonparametric sign test (11).

with glucose-1-14 $\mathrm{C}$ or glucose-6- ${ }^{14} \mathrm{C}$, the addition of epinephrine $(10 \mu \mathrm{g}$ per $\mathrm{ml})$ still stimulated an approximately two- and threefold production of glycerol and fatty acids, respectively (Table VI); however, there was no concurrent stimulation in production of ${ }^{14} \mathrm{CO}_{2}$ from glucose--14 $\mathrm{C}$ labeled in either the 1 or 6 position, although the formation of ${ }^{14} \mathrm{CO}_{2}$ from glucose-1-14 $\mathrm{C}$ was 20 times greater than from glucose- $6-{ }^{-14} \mathrm{C}(\mathrm{p}=0.017)$. The larger values for glycerol and fatty acid production in this Table are due to the subtraction of a medium

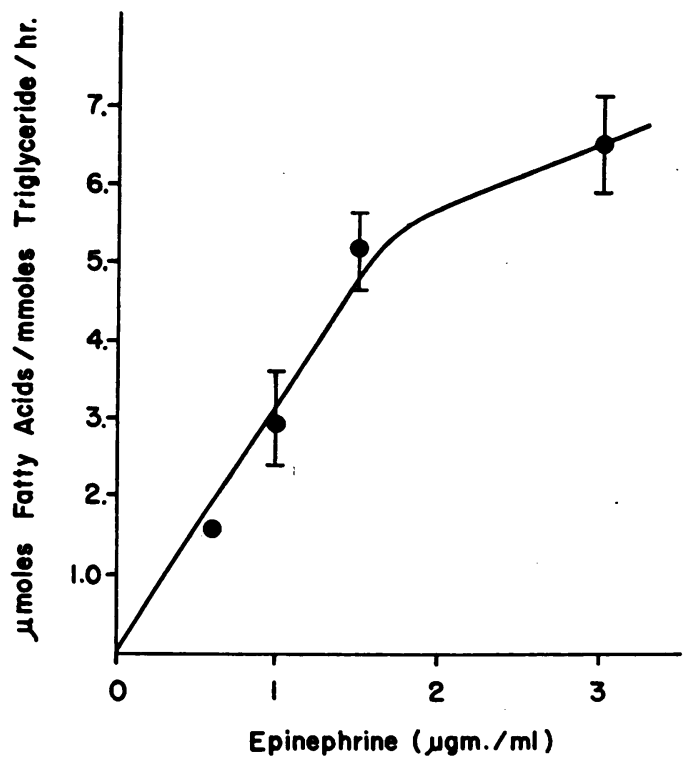

Fig. 2. DOSE-RESPONSE CURVE OF EPINEPHRINE ON PRODUCTION OF FATTY ACID BY ISOLATED HUMAN FAT CELLS. Points represent means of five experiments, with the standard error of the mean represented between the bars. Experimental conditions were the same as in Table I. blank instead of tissue blank from the experimental values.

Effects of growth hormone and cortisol. With an incubation system similar to that used in the studies on epinephrine, it was found that growth hormone $(5 \mu \mathrm{g}$ per $\mathrm{ml})$ in the presence of cortisol $(1 \mu \mathrm{g}$ per $\mathrm{ml})$ led to a small production of fatty acids by human fat cells after an incubation period of 4 hours (Table II). This effect was not increased by raising the concentration of growth hormone to $10 \mu \mathrm{g} \cdot \mathrm{per} \mathrm{ml}$. When either hormone was used alone or when bovine growth hormone was used with cortisol, no significant rise in concentration of fatty acids was observed (Table VII). Since there is evidence which suggests that the pituitary gland contains hormones other than growth hormone that might be responsible for the mobilization of fatty acids from adipose tissue (4, 12,13 ), the effects of a crude pituitary powder were examined to see if it contained more active lipolytic agents than growth hormone. The pow-

TABLE $V$

Effects of epinephrine $(3 \mu \mathrm{g} / \mathrm{ml})$ on oxygen uptake and fatty acid and glycerol production by isolated human fat cells*

\begin{tabular}{|c|c|c|c|}
\hline Treatment & $\begin{array}{l}\text { Oxygen } \\
\text { uptake }\end{array}$ & $\begin{array}{l}\text { Fatty acid } \\
\text { release }\end{array}$ & $\begin{array}{l}\text { Glycerol } \\
\text { release }\end{array}$ \\
\hline & $\underset{h r}{\operatorname{minole} /}$ & $\underset{\text { mmole } / h r}{\text { mmoles/ }}$ & $\begin{array}{c}\text { umoles/ } \\
\text { mmole/hr }\end{array}$ \\
\hline None & $30 \pm 5$ & $0.17 \pm 0.04$ & $0.47 \pm 0.08$ \\
\hline$+\underset{(3 \mu \mathrm{g} / \mathrm{ml})}{\text { Epinephrine }}$ & $43 \pm 6$ & $3.3 \pm 1.2$ & $3.4 \pm 0.9$ \\
\hline p versus control & 0.03 & 0.03 & 0.03 \\
\hline
\end{tabular}

* Fat cells (approximately $624 \mu$ moles of triglyceride) were incu bated in $2 \mathrm{ml}$ of albumin-phosphate buffer for 1 hour in the absence glucose. Results are means of five experiments \pm standard error the mean, and the significance of the difference (p) was calculated by nonparametric sign test (11) 
TABLE VI

Effect of epinephrine on lipolysis and glucose oxidation in human adipose cells*

\begin{tabular}{|c|c|c|c|c|c|}
\hline \multirow{2}{*}{$\begin{array}{l}\text { Radioactive } \\
\text { label in medium }\end{array}$} & \multirow[b]{2}{*}{ Hormone } & \multicolumn{2}{|c|}{ Release of } & \multirow{2}{*}{$\begin{array}{c}\text { Glucose converted } \\
\text { to } \mathrm{CO}_{2}\end{array}$} & \multirow{2}{*}{$\begin{array}{c}p \\
\text { versus } \\
\text { control }\end{array}$} \\
\hline & & Fatty acids & Glycerol & & \\
\hline Glucose-1-14C & $\begin{array}{l}\text { None } \\
\text { Epinephrine }\end{array}$ & $\begin{array}{r}7.4 \pm 2.1 \\
25.9 \pm 7.1\end{array}$ & $\begin{array}{r}7.8 \pm 1.1 \\
16.2 \pm 2.8\end{array}$ & $\begin{array}{l}0.99 \pm 0.3 \\
1.23 \pm 0.2\end{array}$ & 0.31 \\
\hline
\end{tabular}

* Fat cells (approximately $20 \mu$ moles of triglycerides) were incubated in $1 \mathrm{ml}$ of an albumin-bicarbonate buffer in the presence of glucose $\left(5.6 \mathrm{mM}\right.$ ), glucose ${ }^{-14} \mathrm{C}$ (final specific activity, $0.02 \mu \mathrm{c} / \mu$ mole), and epinephrine $(10 \mu \mathrm{g} / \mathrm{ml}$ ) for $1 \mathrm{hour}$. Results are means of five experiments \pm standard errors of the mean. Tissue blanks were not subtracted from values in the Table.

TABLE VII

Effects of growth hormones and cortisol on fatty acid production by isolated human fat cells*

\begin{tabular}{|c|c|c|c|c|}
\hline \multirow[b]{2}{*}{ Additions to medium } & \multirow{2}{*}{$\begin{array}{l}\text { No. of } \\
\text { experi- } \\
\text { ments }\end{array}$} & \multicolumn{2}{|c|}{ Fatty acid production } & \multirow{2}{*}{$\begin{array}{c}\mathrm{p} \\
\text { versus } \\
\text { control }\end{array}$} \\
\hline & & Control & + hormone (s) & \\
\hline & \multicolumn{3}{|c|}{ umoles $/$ mmole $T G / 4 \mathrm{hr}$} & \\
\hline $\begin{array}{l}\text { Human growth hormone } \\
\qquad(5 \mu \mathrm{g} / \mathrm{ml})\end{array}$ & 8 & $-0.25 \pm 1.8$ & $-0.10 \pm .8$ & 0.22 \\
\hline Cortisol $(1 \mu \mathrm{g} / \mathrm{ml})$ & 8 & $-0.25 \pm 1.8$ & $-0.16 \pm 1.4$ & 0.22 \\
\hline $\begin{array}{l}\text { Bovine growth hormone } \\
\qquad(5 \mu \mathrm{g} / \mathrm{ml})+\text { cortisol }(1 \mu \mathrm{g} / \mathrm{ml})\end{array}$ & 4 & $+0.72 \pm 1.2$ & $+0.59 \pm .5$ & 0.25 \\
\hline
\end{tabular}

* Isolated fat cells (199 $\mu$ moles of triglyceride) were incubated for 4 hours in $2 \mathrm{ml}$ of albumin-bicarbonate buffer containing glucose $(5.6 \mathrm{mM})$. The results are expressed as means \pm standard errors of the mean, and the significance of the difference $(p)$ was calculated by a nonparametric sign test (11).

der was an acetone-dried preparation of whole human pituitary glands and would be expected to contain about $5 \%$ by weight of human growth hormone and 0.1 to $0.3 \%$ by weight of corticotropin. We first tested the extract on isolated fat cells of the rat to determine whether it contained any substances that might interfere with lipolysis. As shown in Table VIII, the powder markedly increased the production of glycerol and fatty acids from adipose cells of the rat, but when the same pituitary extract and cortisol (1 $\mu \mathrm{g}$ per $\mathrm{ml}$ ) were added to the incubation medium with human adipose cells, no effect on lipolysis was seen (Table VIII). This suggests that corticotropin and other pituitary peptides, such as thyrotropin, do not stimulate lipolysis in human adipose cells. Support for this came from four experiments which showed that when Oxycelpurified corticotropin was added at a concentration of $5 \mu \mathrm{g}$ per $\mathrm{ml}$ to a preparation of human adipose cells, the fatty acid level only altered from
$0.295 \pm 0.1$ to $0.30 \pm 0.35 \mu$ moles per $\mathrm{ml}$ of cell suspension per 2 hours. This preparation of hormone had been previously shown to be active on rat adipose cells.

\section{Discussion}

Previous studies have reported that epinephrine has only a small effect on lipolysis in isolated human adipose tissue (14-16). Hamosh, Hamosh, Bar Maor, and Cohen (14) concluded that subcutaneous adipose tissue of man either responds sluggishly to epinephrine per se or that their experimental conditions were unsuitable for revealing it. The present studies with subcutaneous adipose cells isolated from man demonstrate a marked effect of epinephrine on lipolysis, as judged by the formation of fatty acids and glycerol, although relatively large amounts of hormone were required to produce it. At the same time, the oxygen consumption of these cells was 
TABLE VIII

Effects of pituitary extracts on lipolysis in fat cells isolated from man and the rat*

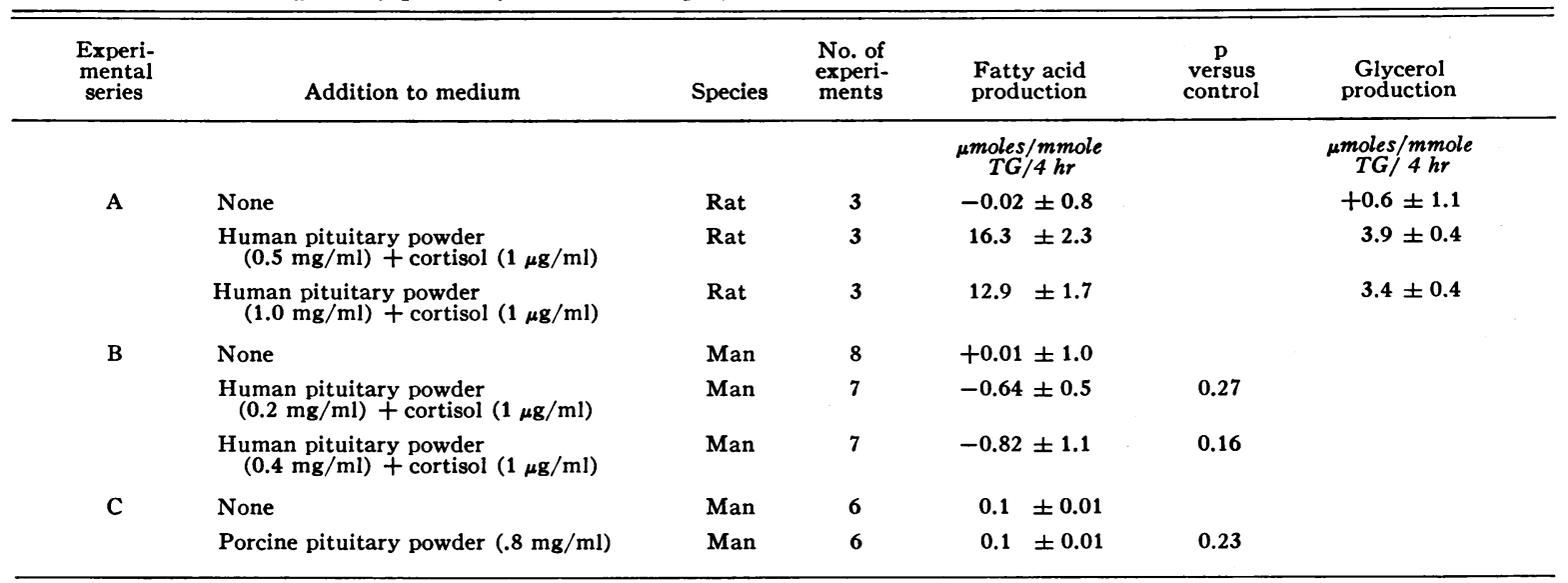

* Free fat cells (227 $\mu$ moles of triglyceride) were incubated for 4 hours in $2 \mathrm{ml}$ of an albumin-bicarbonate buffer containing glucose (5.6 m M). Three male rats of the Charles River breed (mean weight, $150 \mathrm{~g}$ ) were killed by decapitation, and their epididymal adipose tissue was treated in a similar manner to the human tissue. Results are means \pm standard errors of the mean, and the significance of the difference (p) was calculated by a nonparametric sign test (11).

stimulated by epinephrine; this probably represents activation of the esterification pathway by the fatty acids liberated during lipolysis (17). The effect of epinephrine on lipolysis was observed in both Krebs-Ringer phosphate and bicarbonate buffers in the presence and absence of glucose (Tables $\mathrm{V}$ and VI). When ${ }^{14} \mathrm{C}$-labeled glucose was added to the medium, 20 times more glucose- $1-{ }^{14} \mathrm{C}$ was converted to ${ }^{14} \mathrm{CO}_{2}$ than glucose-6- ${ }^{14} \mathrm{C}(\mathrm{p}=0.017)$, although utilization of either was not augmented by epinephrine when, at the same time, lipolysis was accelerated.

It has been observed in the rat that insulin, in concentrations as low as $10 \mu \mathrm{U}$ per $\mathrm{ml}$, can reduce the release of fatty acids from adipose tissue that has been stimulated with epinephrine, even when glucose is not present in the incubation medium (18). This antilipolytic effect of insulin was examined with human adipose cells in Table IV. Although the mean release of fatty acids was less when insulin was added with epinephrine to the incubation medium, the difference was not statistically significant $(p=0.16)$.

The effect of epinephrine on the formation of fatty acids by isolated human adipose cells was sixfold greater than the combined effect of growth hormone and cortisol. The response to growth hormone could not be increased by raising its concentration in the medium to $10 \mu \mathrm{g}$ per $\mathrm{ml}$. In any case, the amounts of hormones that were used exceeded the maximal amounts reported to occur in the plasma of man. Raben and Hollenberg (19) used 20 times the dosage of human growth hormone as in the present experiments (in the absence of a glucocorticoid) and obtained no greater response from human adipose tissue.

Human growth hormone at a concentration of $5 \mu \mathrm{g}$ per $\mathrm{ml}$ and cortisol at a concentration of 1 $\mu \mathrm{g}$ per ml used separately did not stimulate formation of fatty acids; when used together they caused a small production of fatty acids. This observation supports the experiments of Fain, Kovacev, and Scow (20), which suggested that a synergistic action exists between growth hormone and a glucocorticoid in the stimulation of lipolysis in isolated adipose cells of the rat. It also extends the observations of Burns and Hales (21), who found that human growth hormone $(100 \mu \mathrm{g}$ per incubation flask) and prednisolone $(0.8 \mu \mathrm{g}$ per flask) stimulated the release of glycerol from human adipose cells of perirenal tissue, whereas prednisolone alone had no such effect.

The effect of human growth hormone and cortisol on fatty acid production is small but probably real. Two of the 17 experiments in Table II did not show a response to these hormones, whereas the others displayed a small and variable release of fatty acids. This variation is not solely attributable to the different types and amounts of anesthetic agents administered to each patient; for 
instance, patient W. C. had spinal anesthesia, yet his tissue released very small amounts of fatty acids when stimulated with growth hormone and cortisol. Since all patients had undergone an overnight fast before operation, it would be expected that their adipose tissue would release fatty acids into the incubation medium. However, the control incubations of 4 of 11 patients were taking up fatty acids, although this did not appear to interfere with the response to growth hormone and cortisol. When bovine growth hormone was substituted for human growth hormone, there was no increment in the production of fatty acids by human adipose cells.

There is evidence which suggests that the pituitary gland contains hormones other than growth hormone that might be involved in the mobilization of fat $(4,12,13)$. However, a crude human pituitary powder, which was active on isolated fat cells of the rat, did not stimulate the production of fatty acids by isolated human adipose cells. This makes it unlikely that the human pituitary gland contains more active lipolytic agents than growth hormone, although it does not exclude the possibility that there are lipolytic agents present in human pituitary glands which are not in an active form in the unfractionated gland, or that the pituitary preparation contains substances which interfere with the action of such lipolytic agents. On the other hand, it suggests that corticotropin, which is a potent lipolytic agent in the rat, does not stimulate lipolysis in human adipose tissue in vitro. This was found when it was used at a concentration of $5 \mu \mathrm{g}$ per $\mathrm{ml}$ and confirms the reports of others (19).

It is difficult to estimate the relative importance of epinephrine and growth hormone with cortisol in the mobilization of fatty acids from adipose tissue from the present studies. In man, intramuscular injections of epinephrine (1) or human growth hormone (3) will produce approximately similar rises of plasma fatty acids (from about 0.5 to about $2 \mu \mathrm{Eq}$ per $\mathrm{ml}$ ). It was surprising that growth hormone and cortisol were so much less effective than epinephrine in stimulating the production of fatty acids from subcutaneous adipose cells of the anterior abdominal wall of man in vitro. This could be partly due to a difference in the mechanism of action of growth hormone and epinephrine. The effect of epinephrine on rat adipose tissue occurs more quickly than that of growth hormone and a glucocorticoid, the effect is greater in magnitude, and it cannot be suppressed by such agents as puromycin and actinomycin D, which block the effect of growth hormone and dexamethasone (20). This points to a difference in the mechanisms of action of epinephrine and growth hormone, and the conditions of incubation in vitro might not be entirely suitable for the expression of the latter. However, it is possible that adipose tissue in various locations responds differently to the same lipolytic agent, so that it is difficult to draw conclusions on the relative efficacy of these agents in elevation of the plasma fatty acids in man when adipose tissue from only one location has been examined in vitro.

\section{References}

1. Dole, V. P. A relation between non-esterified fatty acids in plasma and the metabolism of glucose. J. clin. Invest. 1956, 35, 150.

2. Havel, R. J., and A. Goldfien. The role of the sympathetic nervous system in the metabolism of free fatty acids. J. Lipid Res. 1959, 1, 102.

3. Raben, M. S., and C. H. Hollenberg. Effect of growth hormone on plasma fatty acids. J. clin. Invest. 1959, 38, 484.

4. Levin, L., and R. K. Farber. Hormonal factors which regulate the mobilization of depot fat to the liver. Recent Progr. Hormone Res. 1952, 7, 399.

5. Fritz, I. B. Control of rates of fatty acid metabolism. Factors influencing the rates of long-chain fatty acid oxidation and synthesis in mammalian systems. Physiol. Rev. 1961, 41, 52.

6. Rodbell, M. Metabolism of isolated fat cells. I. Effects of hormones on glucose metabolism and lipolysis. J. biol. Chem. 1964, 239, 375.

7. Galton, D. Studies on the respiratory metabolism of isolated human adipose cells. Biochem. J. 1966, $101,164$.

8. Dole, V. P., and H. J. Meinertz. Microdetermination of long-chain fatty acids in plasma and tissues. J. biol. Chem. 1960, 235, 2595.

9. Wieland, O. Assay of glycerol in Methods of Enzymatic Analysis, 1st ed., H. U. Bergmeyer, Ed. New York, Academic Press, 1963, p. 211.

10. Bray, G. A. A simple efficient liquid scintillator for counting aqueous solutions in a liquid scintillation counter. Analyt. Biochem. 1960, 1, 279.

11. Siegel, S. The sign test in Non-parametric Statistics. New York, McGraw-Hill, 1956, p. 68.

12. Fry, E. G. The effect of adrenalectomy and thyroidectomy on ketonuria and liver fat content of the albino rat following injection of anterior pituitary extract. Endocrinology 1937, 21, 283. 
13. Payne, R. W. Studies on the fat-mobilizing factor of the anterior pituitary gland. Endocrinology $1949,45,305$.

14. Hamosh, M., P. Hamosh, J. A. Bar-Maor, and H. Cohen. Fatty-acid metabolism by human adipose tissues. J. clin. Invest. 1963, 42, 1648.

15. Björntrop, $P$. The fatty acid release and lipolysis of human subcutaneous adipose tissue in vitro. Metabolism 1964, 13, 1318.

16. Mosinger, B., E. Kuhn, and V. Kujalová. Action of adipokinetic hormones on human adipose tissue in vitro. J. Lab. clin. Med. 1965, 66, 380.

17. Ball, E. G., and R. L. Jungas. On the action of hormones which accelerate the rate of oxygen consumption and fatty acid release in rat adipose tissue in vitro. Proc. nat. Acad. Sci. (Wash.) 1961, 47, 932.
18. Jungas, R. L., and E. G. Ball. Studies on the metabolism of adipose tissue. XII. The effect of insulin and epinephrine on free fatty acid and glycerol production in the presence and absence of glucose. Biochemistry 1963, 2, 383.

19. Raben, M. S., and C. H. Hollenberg. Growth hormone and the mobilization of fatty acids in Ciba Foundation Colloquia on Endocrinology, 1960, vol. 13, p. 89.

20. Fain, J. N., V. P. Kovacev, and R. O. Scow. Effect of growth hormone and dexamethasone on lipolysis and metabolism in isolated fat cells of the rat. J. biol. Chem. 1965, 240, 3522.

21. Burns, T. W., and C. N. Hales. Regulation of lipolysis in isolated human adipose-tissue cells. Lancet 1966, 1, 796. 